\title{
STUDENT RESOURCE ON NEWTON'S LAW CONCEPTS REVIEWING FROM GENDER: IDENTIFICATION USING OPEN-ENDED QUESTIONS
}

\author{
Meiliani $^{1^{*}}$, Tanti ${ }^{2}$, Fauzan Sulman ${ }^{3}$ \\ ${ }^{1}$ Department of Physics Education, Undergraduate Student, Universitas Islam Negeri Sulthan Thaha \\ Saifuddin, Jambi, Indonesia \\ ${ }^{2,3}$ Department of Physics Education, Universitas Islam Negeri Sulthan Thaha Saifuddin, Jambi, Indonesia
}

*Corresponding author: Meilianijambi21@gmail.com

\begin{tabular}{ll}
\hline Article Info & ABSTRACT \\
\cline { 1 - 2 } $\begin{array}{l}\text { Article history: } \\
\text { Received: November 01, }\end{array}$ & $\begin{array}{l}\text { This article aims to find out the resources activated by students in } \\
\text { solving Newton's laws in terms of gender. This research is a } \\
\text { quantitative descriptive study with two open test instruments. This } \\
\text { research was conducted on 10th-grade students at SMK N 1 Muaro }\end{array}$ \\
$\begin{array}{l}\text { Accepted: November 20, } \\
2021\end{array}$ & $\begin{array}{l}\text { Jambi with 11 female students and 11 male students. The facts } \\
\text { obtained in this study indicate that students' thinking about }\end{array}$ \\
Published: November 30, & $\begin{array}{l}\text { Newton's law is still lacking during the learning process. Based on } \\
\text { the analysis results of the level of understanding of student } \\
\text { concepts, female students understand better than male students. }\end{array}$ \\
$\begin{array}{l}\text { Overall, students fail to summon relevant knowledge when facing } \\
\text { Keywords: }\end{array}$ & $\begin{array}{l}\text { problems in the form of phenomena. In addition, they failed to use } \\
\text { the knowledge they gained to answer questions. Students' abilities } \\
\text { are activated when they understand a phenomenon influenced by } \\
\text { Newton's law }\end{array}$ \\
$\begin{array}{l}\text { Open-ended } \\
\text { Resource }\end{array}$ &
\end{tabular}

\section{RESOURCE PESERTA DIDIK PADA KONSEP HUKUM NEWTON DITINJAU DARI GENDER: IDENTIFIKASI MENGGUNAKAN SOAL OPEN-ENDED}

\section{Kata Kunci: \\ Hukum Newton \\ Open-ended \\ Resource}

\begin{abstract}
ABSTRAK
Artikel ini bertujuan mengetahui resource yang diaktifasi oleh mahasiswa dalam menyelesaikan hukum-hukum Newton yang ditinjau berdasarkan jenis kelamin. Penelitian ini merupakan penelitian deskriptif kuantitatif dengan instrumen tes dua butir soal yang bersifat open-ended. Penelitian ini dilakukan pada siswa kelas X SMK N 1 Muaro Jambi dengan 11 siswa perempuan dan 11 siswa laki-laki. Fakta-fakta yang diperoleh dalam penelitian ini menunjukkan kurangnya ide-ide siswa mengenai hukum Newton selama proses pembelajaran. Berdasarkan hasil analisis tingkat pemahaman konsep, siswa perempuan lebih baik tingkat pemahamannya dibandingkan siswa laki-laki. Secara keseluruhan, siswa gagal memanggil pengetahuan yang relevan ketika dihadapkan pada masalah berupa fenomena yang sering ditemui. Selain itu, mereka gagal menggunakan pengetahuan yang mereka peroleh untuk menjawab pertanyaan. Kemampuan siswa teraktivasi ketika memahami suatu fenomena yang dipengaruhi oleh ide-ide orisinil siswa dari pengalaman pribadinya.
\end{abstract}




\section{INTRODUCTION}

Some researchers reveal that before starting the lesson students already have prior knowledge or initial conceptions obtained through everyday personal experience. Students' prior knowledge is generally naive, it is said to be naive because their initial expertise is incomplete [1], [2], [3] and still in separate knowledge [4], [5]. Students' naive ideas are influenced by daily activities in their environment, and the fact that inappropriate assumptions about student resources lead to naive ideas is clearly visible when learning begins [6], [7], students do not understand the concepts scientifically appropriate [4]. Initial knowledge may be different from the concept of scientists, this difference in concept is called misconception, and this will be an obstacle for students when receiving learning. If the understanding of the concept has been wrong from the start, it will continue to be wrong to the next level of understanding and can injure the scientific concepts of science [8].

Conceptual understanding can be interpreted as the ability of students to understand the meaning of concepts scientifically. Because initial knowledge must be complemented by scientific knowledge, understanding the concept is considered important because the conception of learning refers to a constructivist view. Process The student's ability to understand concepts is acquired through personal experience and appropriate learning. In science, understanding concepts is an important indicator to achieve science learning objectives [9]-[11] One of the achievements of understanding concepts is when there is an improvement in misconceptions, which includes strengthening and deepening current understanding [12], [13]. The issue of gender in education is one of the most crucial issues. Gender differences can affect the exact learning process during elementary school (SD), junior high school (SMP), and senior high school (SMA). Gender differences themselves can change from time to time. Gender differences can also affect students' learning motivation [2], [14] and prior knowledge, wherein in the learning process, female students are more dominant than male students [15]-[17]. Although overall research like this should be studied more deeply, in other words the understanding of differences in the dominance of the learning process caused by gender differences is still very interesting to study.

Physics research, especially research related to the resources that students activate when solving problems related to Newton's laws, tends to be rarely done. Even though some everyday phenomena that we often encounter sometimes have something to do with Newton's laws [9], [18]. Research of Resources specifically for physics teachers can be a breakthrough to find out the abilities that are activated in students and more specifically in terms of gender differences, especially for science students in SMK in understanding a phenomenon, especially in physics material that often occurs. Students' naive ideas are formed from their personal experiences, both in the community and in the school environment, which is in line with several research studies that show some student activation [5], [14], [19], long-term personal experiences affect students' understanding significantly when viewed from the gender differences of students. Some of the concepts they found were obtained through everyday experiences including through electronic media [7], [20], [21] and real life adventures [21]-[24]. Therefore, in this article, we will discuss what resources are activated by students when solving Newton's law questions, and the level of understanding of students' concepts in Newton's law material based on gender differences specifically in vocational schools.

\section{METHOD}

This research is descriptive quantitative research. This study describes in detail the research data obtained using the activity analysis method [25]. The purpose of this study is to reveal what resources are activated by students when solving Newton's law problems 
and to determine the level of understanding of students' Newton's law concepts. This research was conducted on 22 students consisting of 11 female students and 11 male students at SMK N 1 Muaro Jambi. The instrument used in this study is an item description test, part of two open-ended questions. Open-ended is chosen because it allows students to demonstrate a deeper understanding of the application of physics principles. The data obtained in this study is quantitative. Quantitative data is obtained from the scores obtained from the questions given [26], [27]. The researcher obtained the data through the test sheet to understand the concept of Newton's law; then, the researcher analyzes it quantitatively. The researcher gives a score for each student's answer where if the student's answer is correct, it will be given a score of 5 (five), and if he does not answer the question, he will get a score of 1 (one) according to the predetermined criteria. The criteria used by researchers in analyzing student learning outcomes regarding Newton's law in this study are given with five value criteria, with details as follows: Score 5 with the criteria of being able to answer all indicators well, then score four if it meets the criteria able to try to answer all indicators well, then get a score of 3 if you are in the criteria of only being able to answer one indicator, then get a score of 2 with the criterion of not being able to answer all indicators correctly, and finally with the criterion of not answering the question at all and given a score of 1 .

Figure 1 shows the procedures carried out in this study. The first problem shows an object that does not experience movement, whether the object has a force. The second problem presents two people who have different masses pushing each other in opposite directions with the same force. Figure 1 shows the procedures carried out in this study.

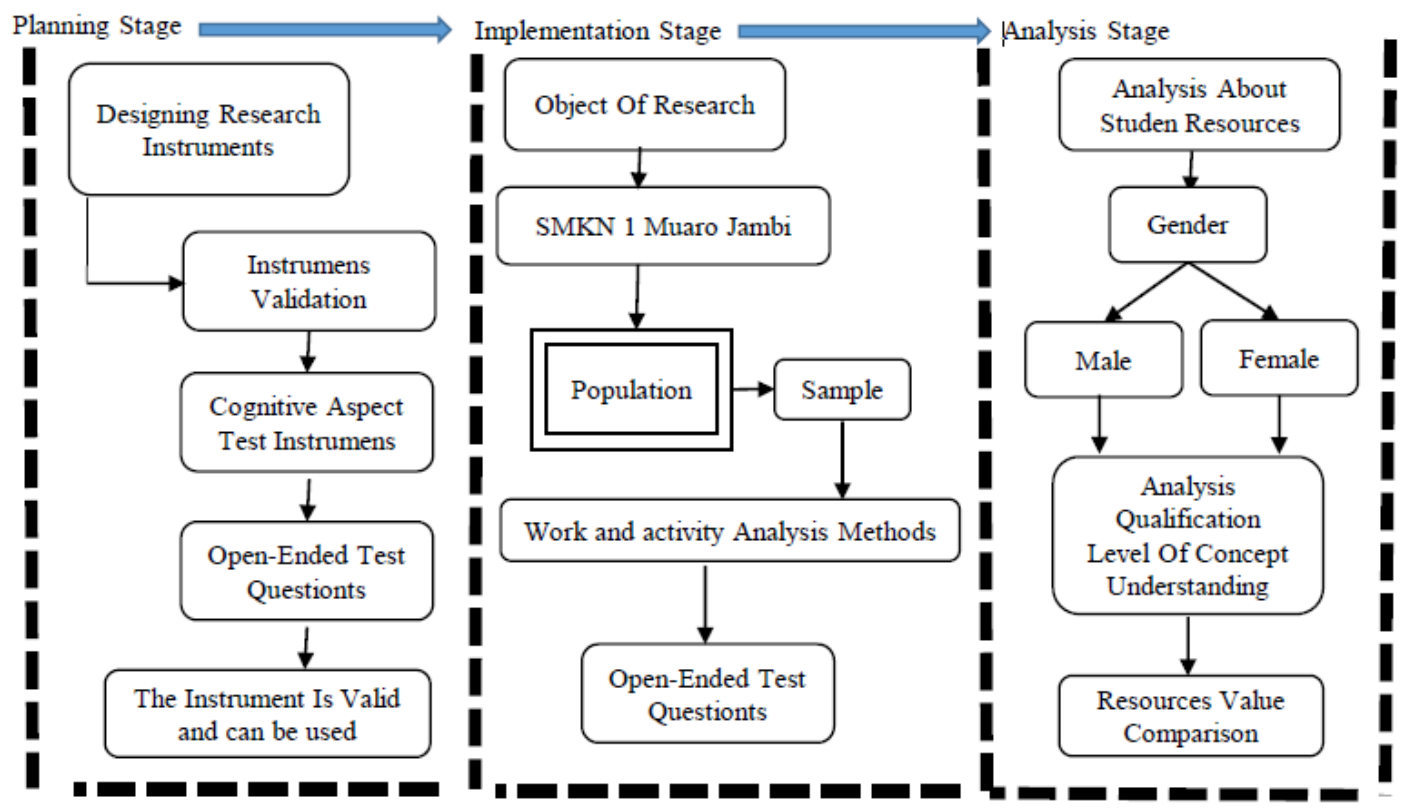

Figure 1. Research Procedure

\section{RESULTS AND DISCUSSION}

\subsection{Resources that Students Activate}

This article will discuss what resources are activated by students in Newton's law material through 2 questions related to Newton's law. In this section, students' answer choices and resources activated by students will be discussed in answering questions related to Newton's law. The form of description questions that researchers use in this study is to see students' understanding of the concept of Newton's law in determining 
whether an object has a force if the object does not experience motion. The question can be seen in Table 1 below.

Table 1. Question Number 1

\begin{tabular}{cc}
\hline No & Open-Ended Question \\
\hline 1 & There is an object that is at rest does not experience movement. Can it be \\
said that it has a force? If so, it has an explanatory force does it not have \\
an explanatory force?
\end{tabular}

The research has revealed various facts on student resources in answering Newton's law questions. Some students indicated the activation of their resources in providing answers to solve or answer the questions given. One form of student answers from question no. 1 in answering open-ended questions such as Table 1 can be seen in Figure 2 .

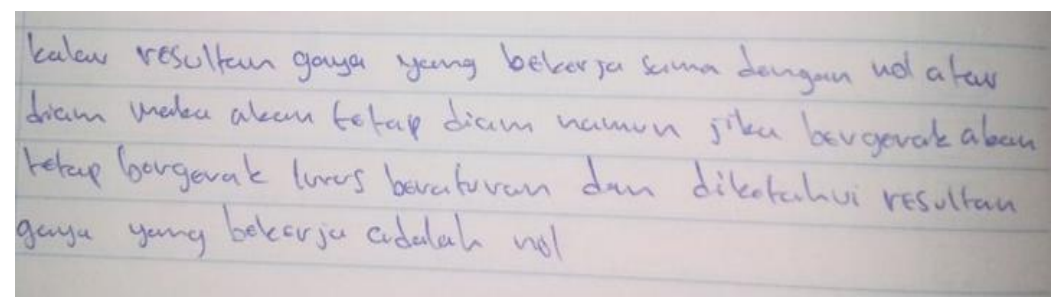

Figure 2. Student Answers from Question Number 1

In answering question number 1 , as seen in the picture above, it shows how students immediately gave answers in accordance with the understanding of Newton's second law that they had received, without looking at the further questions that were explained. In answering question number 1, the distribution of students' answer scores is shown in Figure 3.

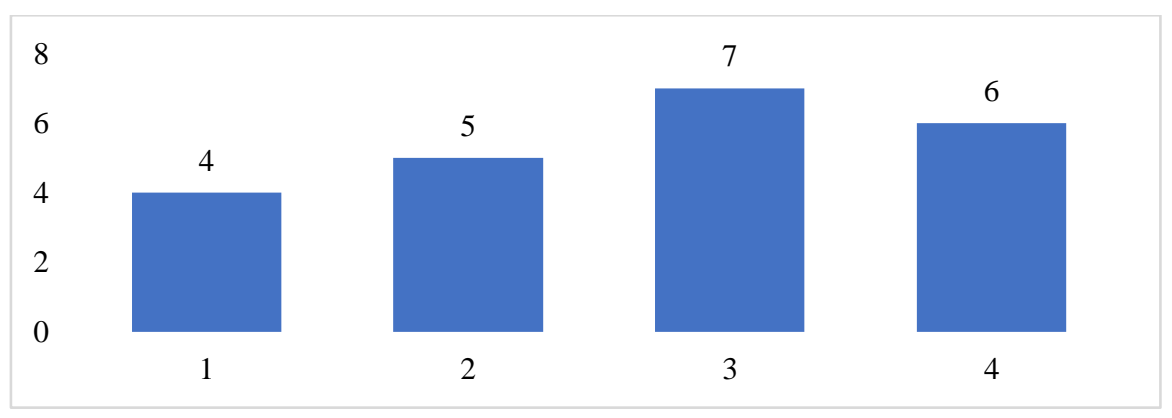

Figure 3. Graph of Student Answer Scores on Question Number 1

Based on the results obtained by students in answering question number 1 above, students' understanding of Newton's law concepts tends to be sufficient. None of the students answered the question correctly with the explanation. As many as seven students can answer the question correctly but are not accompanied by the explanation. The phenomenon is shown by the researcher in question number 1, to test the ability of students to understand concepts where students are asked to explain whether there is a force that works if the object does not experience movement. Based on the students' answers analyzed by researchers, students have tried to answer that "when an object moves, it will cause a force." Students make mistakes in answering question number 1 because they do not activate the knowledge of Newton's first law that they have obtained. If they can use Newton's first law knowledge, they will quickly answer question number 1, accompanied by an explanation. Because an object is at rest, it does not experience movement, where force means a pull or push that can cause an object to move, and motion is a displacement 
caused by force, then when an object will experience movement without a force. The following is the phenomenon of question number 2 , which is shown in the following Table 2 .

Table 2. Question Number 2

\begin{tabular}{cc}
\hline No & Open-Ended Question \\
\hline 2 & $\begin{array}{c}\text { In a room, there is a person with a small mass, and another person has a } \\
\text { large mass. They push each other in opposite directions but with the same } \\
\text { force; explain which of them moves further? }\end{array}$ \\
\hline
\end{tabular}

The facts obtained in the study are that there are various kinds of student answers that indicate the form of activation of previously owned resources. As for one form of student answers from question no. 2, which is the result of open-ended questions as above, can be seen in Figure 4.

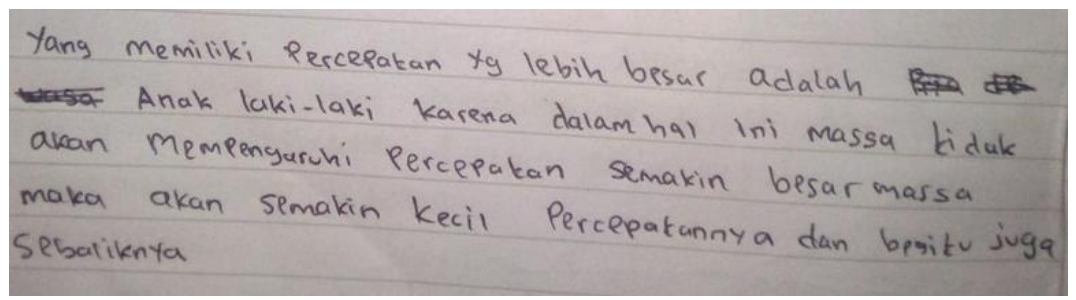

Figure 4. Student Answers from Question Number 2

From the answers above, it can be seen that students answered directly activated from their initial understanding. Some students gave answers based on their experience in the school environment and the surrounding environment. In answering question number 2 , the following distribution of student answer scores is shown in the following Figure 5.

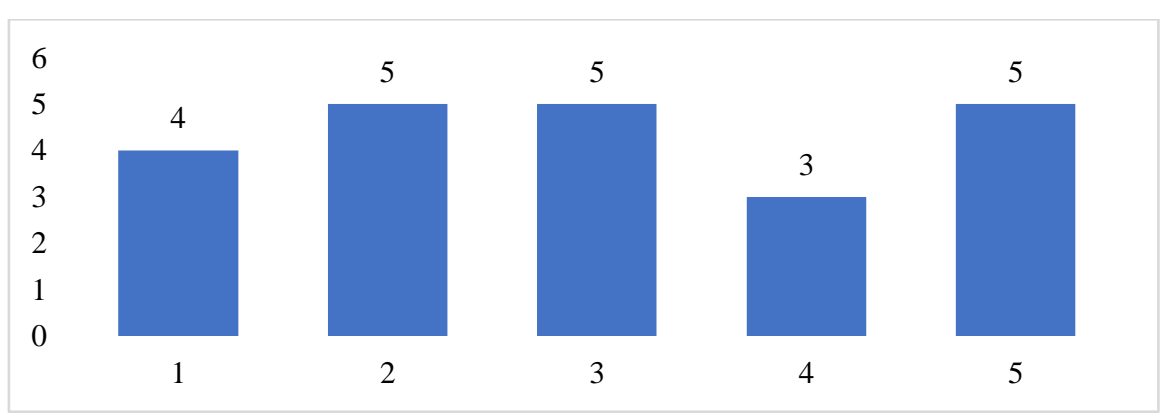

Figure 5. Graph of Student Answer Scores on Question Number 2

Based on the results obtained by students in answering question number 2 above, students' understanding of Newton's law concepts tends to be sufficient. There are as many as five students who can answer questions correctly and are accompanied by explanations. There are as many as five students who can answer the question correctly but are not accompanied by the explanation. The phenomenon displayed by the researcher in question number 2, is to test the ability of students to understand concepts where students are asked to explain which of two people who have different masses and push each other have a more significant acceleration. Based on the answers researchers have analyzed, the average student tries to explain that "a large mass will affect the magnitude of the acceleration." Students make mistakes in answering question number 2 because, on average, students do not activate the knowledge of Newton's third law that they have obtained. If they can use the knowledge of Newton's third law, they will quickly answer question number 2, which is accompanied by an explanation. Because in Newton's third law, it can be said that the directions are opposite and have the same magnitude. Moreover, even though the force that 
works together is large, the mass will affect the acceleration, where someone who has a smaller mass will have a more significant acceleration because Newton's second law works on this phenomenon [9], [10], Not because the mass is large will have a significant acceleration. However, a small mass will have a large acceleration.

\subsection{Level of Understanding of Student Concepts Based on Gender}

The number of students in this study was 22 students consisting of 11 male students and 11 female students. The following is the comparison of the average scores between male and female students in Table 3.

Table 3. Table of average student scores based on gender

\begin{tabular}{cccc}
\hline & N & Mean & Std. Deviation \\
\hline Female & 11 & 52,00 & 15,748 \\
Male & 11 & 49,64 & 11,994 \\
Valid N (listwise) & 11 & & \\
\hline
\end{tabular}

The data are shown from Table 3 clearly shows the different levels of understanding of the concept seen from the gender difference. The comparison of student scores in terms of gender can be seen clearly in graph three below.

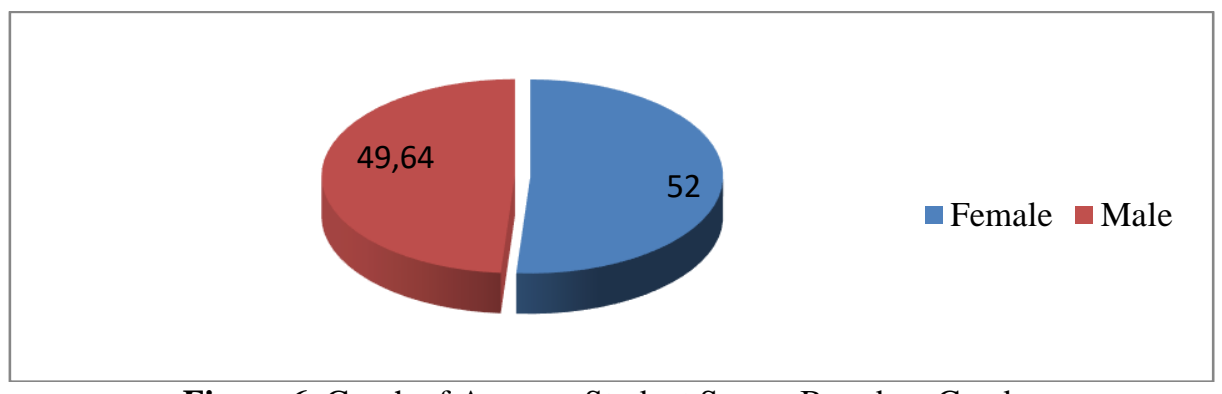

Figure 6. Graph of Average Student Scores Based on Gender

Figure 6 shows that the average score obtained by students is based on gender. Gender differences are one part of the differences that occur in the classroom. Based on table 3 above, it can be seen that female students are more dominant than male students considering the number of female students compared to the number of male students. However, the study results show the fact that the average value of understanding of female students is slightly better than that of male students. The average understanding of women's concepts is 52.00 , and the average male is only 49.64 . The facts found that are found to be able to explain the influence of gender differences, however, cannot be denied by the researchers, with the difference in scores being so small, there may be other factors that determine student learning outcomes, such as the environment, as well as the economy which is interesting if studied in the future. The facts obtained in this study are considered gender differences in learning to be a factor that affects students' learning motivation and initial knowledge. [2], [28], [29]. The facts found above illustrate that it is likely that from a certain point of view, the dominance of action can be influenced based on the gender of students, which can increase students' motivation and learning abilities.

Based on the analysis results, in number 1, students tried to explain in the form of "when an object moves it will cause a force." In question number 2, students try to explain in the form of "a large mass will affect acceleration." In answering question number 1, they have a good understanding, but when faced with problems in the form of phenomena that are often encountered, they fail to summon relevant knowledge. In answering question 
number 2, they think that if a person's mass is large, it will have a significant acceleration; how can a person who has a small mass have a significant acceleration? The error occurs because they fail to take advantage of the knowledge they have gained, whereas if they can use it well, it will be easier to answer these questions [19], [30]. Research on how student resources are in answering questions in physics has been proven [31], [32], [5], and this is in line with the data found by researchers in research where the level of understanding of female students' concepts is slightly better than male students. men, although it should be studied more deeply from various points of view such as environmental and economic factors in future research. In general, the results of this study clearly show where when students are faced with problems in the form of frequently encountered phenomena, they fail to summon relevant knowledge. They fail to use the knowledge they gain to answer questions. The ability of students to understand a phenomenon is generally influenced by students' naive ideas from their personal experiences, both in the community and in the school environment. The facts contained in this study are very important information for a teacher in carrying out the learning process in the classroom so that students can be directed to a clearer direction in maximizing student learning outcomes, especially students in vocational schools.

\section{CONCLUSION}

In answering Newton's law questions in the context of force and motion, two thoughts emerged, namely (1) objects that move then there is a force that occurs, and objects that are at rest or not moving there are no forces because they think that "There is a force, then there is motion, there is motion, then there is force. (2) on objects that are in motion then no force occurs, and on objects that are at rest or do not experience movement then there is a force that occurs, students assume that "there is motion, then there is no force. And if there is force, then there is no movement." In answering Newton's law questions in the context of mass, acceleration, direction of motion, and force, two forms of thought emerge: (1) if a person has a large mass, then the acceleration he has is greater than the acceleration he experiences. have mass. The smaller one. This thinking occurs because "if the mass is large, then the acceleration is greater". (2). If a person has a smaller mass, then the acceleration he has is greater than that which has a larger mass. This thinking occurs because "if the mass is small, then the acceleration is large". Newton's law problems in the context of force and motion show that students have a source "where there is motion, there is force". Furthermore, thinking about Newton's law problems in the context of mass, force, direction, and acceleration shows that students have a resource "a small mass will cause a large acceleration". Based on the research findings, it can be seen that the ability of female students is slightly better than male students in understanding and analyzing a phenomenon presented in Newton's law material and is generally influenced by students' naive ideas formed from their thinking. In general, their understanding is correct in certain contexts, but not in others. And it can be seen that the level of understanding of students' concepts is still included in the less category. For researchers and teachers, it is very important to identify student-activated resources because by knowing student-activated resources, teachers can consider more appropriate learning and facilities that are certainly more suitable.

\section{REFERENCES}

[1] M. D. Angelo et al., "Frontiers of Fundamental Physics and Physics Education Research,”vol. 145, pp. 589-593, 2014, doi: 10.1007/978-3-319-00297-2.

[2] F. Sulman, "Application of Cooperative Problem Posing and Prior Motivation 
Towards Students Learning Outcomes," Indones. J. Educ. Res., vol. 4, no. 2, pp. 93-96, 2019, doi: 10.30631/ijer.v4i2.126.

[3] M. Dresow, "History and philosophy of science after the practice-turn: From inherent tension to local integration," Stud. Hist. Philos. Sci. Part A, vol. 82, no. January, pp. 57-65, 2020, doi: 10.1016/j.shpsa.2020.01.001.

[4] M. C. Sutarja, Sutopo, and E. Latifa, "Resources Siswa Sma Tentang Konsep Gaya Apung Melalui Closed-Ended Beralasan,” vol. 2, pp. 1315-1320, 2017.

[5] M. R. A. Taqwa, L. Rivaldo, and T. Taurusi, "Resources Siswa SMA tentang Konsep Gaya Archimedes," J. Pendidik. Fis., vol. 6, no. 3, pp. 251-258, 2018, doi: 10.26618/jpf.v6i3.1438.

[6] M. I. J. Putra, M. Junaid, and F. Sulman, "The Ability of the Question and Answer (Q\&A) Method with the Help of Learning Videos against Student Learning Outcomes amid the Covid-19 Pandemic," EDUKATIF J. Ilmu Pendidik., vol. 3, no. 5, pp. 2160-2169, 2021, doi: https://doi.org/10.31004/edukatif.v3i5.768.

[7] F. Sulman, T. Tanti, M. Habibi, and A. Zb, "Pengaruh Media Animasi Berkarakter Islami Terhadap Hasil Belajar Pengetahuan Bumi dan Antariksa," Edumaspul J. Pendidik., vol. 5, no. 1, pp. 135-146, 2021, doi: 10.33487/edumaspul.v5i1.1044.

[8] S. Z. Dewi and H. T. Ibrahim, "Pentingnya Pemahaman Konsep Untuk Mengatasi Miskonsepsi Dalam Materi Belajar IPA di Sekolah Dasar," vol. 13, pp. 130-136, 2019.

[9] R. K. Thornton and D. R. Sokoloff, “Assessing student learning of Newton's laws: The Force and Motion Conceptual Evaluation and the Evaluation of Active Learning Laboratory and Lecture Curricula," Am. J. Phys., vol. 66, no. 4, pp. 338352, 1998, doi: 10.1119/1.18863.

[10] T. F. Scott and D. Schumayer, "Conceptual coherence of non-Newtonian worldviews in Force Concept Inventory data," Phys. Rev. Phys. Educ. Res., vol. 13, no. 1, pp. 1-12, 2017, doi: 10.1103/PhysRevPhysEducRes.13.010126.

[11] S. Ozkazanc and U. D. Yuksel, "Evaluation of Disaster Awareness and Sensitivity Level of Higher Education Students," Procedia - Soc. Behav. Sci., vol. 197, no. February, pp. 745-753, 2015, doi: 10.1016/j.sbspro.2015.07.168.

[12] A. L. M. O. C. Torres, "Understanding and intervening in E-learning in higher education institution," Procedia - Soc. Behav. Sci., vol. 15, pp. 756-760, 2011, doi: 10.1016/j.sbspro.2011.03.178.

[13] M. Fidan and M. Tuncel, Integrating augmented reality into problem based learning: The effects on learning achievement and attitude in physics education, vol. 142. Elsevier Ltd, 2019.

[14] F. Sulman, M. R. A. Taqwa, A. Z. Aminah Zb, R. Rafzan, and A. Fikri, "The Effect of Mathematical Connections on the Mastery of Probability Material," Edumatika J. Ris. Pendidik. Mat., vol. 3, no. 2, pp. 147-157, 2020, doi: 10.32939/ejrpm.v3i2.645.

[15] Y. Lehavi and B.-S. Eylon, Integrating Science Education Research and History and Philosophy of Science in Developing an Energy Curriculum. 2018.

[16] J. Wells, R. Henderson, J. Stewart, G. Stewart, J. Yang, and A. Traxler, "Exploring the structure of misconceptions in the Force Concept Inventory with modified module analysis," Phys. Rev. Phys. Educ. Res., vol. 15, no. 2, p. 20122, 2019, doi: 10.1103/PhysRevPhysEducRes.15.020122.

[17] D. K. Reed, E. Martin, E. Hazeltine, and B. McMurray, "Students' Perceptions of a Gamified Reading Assessment," J. Spec. Educ. Technol., vol. 35, no. 4, pp. 191203, 2020, doi: 10.1177/0162643419856272. 
[18] J. Wells, R. Henderson, A. Traxler, P. Miller, and J. Stewart, "Exploring the structure of misconceptions in the force and motion conceptual evaluation with modified module analysis," Phys. Rev. Phys. Educ. Res., vol. 16, no. 1, 2020, doi: 10.1103/PHYSREVPHYSEDUCRES.16.010121.

[19] A. T. Reyza, S. Muhammad, I. Muhammad, and A. Zainuddin, "Kesulitan Mahasiswa Dalam Memahami Konsep Gaya Dan Gerak," LENSA (Lentera Sains) J. Pendidik. IPA, vol. 10, no. 1, pp. 25-39, 2020, doi: 10.24929/lensa.v10i1.86.

[20] A. Zb, M. E. Setiawan, and F. Sulman, "Pengaruh E-Learning Berbasis Schoology Berbantuan WhatsApp Group terhadap Hasil Belajar Ditengah Pandemi Covid-19," Al-Khidmah, vol. 3, no. 2, pp. 55-60, 2020, doi: 10.29406/al-khidmah.v3i2.2282.

[21] E. Rozal, R. Ananda, A. Zb, and M. Fauziddin, "The Effect of Project-Based Learning through YouTube Presentations on English Learning Outcomes in Physics," AL-ISHLAH J. Pendidik., vol. 13, no. 3, pp. 1924-1933, 2021, doi: 10.35445/alishlah.v13i3.1241.

[22] F. X. Berek, Sutopo, and Munzil, "Pentingnya pengintegrasian hukum newton dalam pembelajaran gaya apung di smp," no. 2008, pp. 570-578, 2016.

[23] A. Zb, D. Novalian, E. Rozal, F. Sulman, and M. Habibi, "STEM Approach in Online Lectures: How Does it Contribute to Cognitive Aspects?," Indones. J. Sci. Educ., vol. 5, no. 2, pp. 88-97, 2021, doi: 10.31002/ijose.v5i2.4365.

[24] A. Zb, M. E. Setiawan, E. Rozal, and F. Sulman, "Investigating Hybrid Learning Strategies: Does it Affect Creativity?," J. Kependidikan J. Has. Penelit. dan Kaji. Kepustakaan di Bid. Pendidikan, Pengajaran dan Pembelajaran, vol. 7, no. 4, pp. 868-875, 2021, doi: 10.33394/jk.v7i4.4063.

[25] M. . S. D. \& V. K. Lodico, Methods in Educational Research: From Theory to Practice, 2nd Edition, no. 3. 2010.

[26] C. N. Creswell, John W ; Poth, A Book Review: Qualitative Inquiry \& Research Design: Choosing Among Five Approaches, vol. 3, no. 1. 2017.

[27] J. W. Creswell, Planning, Conducting, and Evaluating Quantitative and Qualitative Research. 2012.

[28] R. A. Punter, M. R. M. Meelissen, and C. A. W. Glas, "Gender differences in computer and information literacy: An exploration of the performances of girls and boys in ICILS 2013," Eur. Educ. Res. J., vol. 16, no. 6, pp. 762-780, 2017, doi: $10.1177 / 1474904116672468$.

[29] B. S. Steel, R. L. Warner, and D. Lach, "Gender differences in support for scientific involvement in U.S. environmental policy," Sci. Technol. Hum. Values, vol. 35, no. 2, pp. 147-173, 2010, doi: 10.1177/0162243909340259.

[30] S. Bayraktar, "Misconceptions of Turkish pre-service teachers about force and motion," Int. J. Sci. Math. Educ., vol. 7, no. 2, pp. 273-291, 2009, doi: 10.1007/s10763-007-9120-9.

[31] L. M. Goodhew, A. D. Robertson, P. R. L. Heron, and R. E. Scherr, "Student conceptual resources for understanding mechanical wave propagation," Phys. Rev. Phys. Educ. Res., vol. 15, no. 2, p. 20127, 2019, doi: 10.1103/PhysRevPhysEducRes.15.020127.

[32] H. Mulyastuti, S. Sutopo, and A. Taufiq, "Identifikasi Resource Siswa Materi Kesetimbangan dan Titik Pusat Massa," J. Pendidik. Teor. Penelitian, dan Pengemb., vol. 3, no. 5, pp. 598-602, 2018. 